\title{
Factors Influencing External Auditors' Independence of Private Audit Firms in Ethiopia
}

\author{
Addisu Abebe, Barassa Balguda, Mathewos Yure, Kanbiro Orkaido, Belay Batiso \\ Furra Institute of Development Studies and Education, Furra College, Yirgalem, Ethiopia, East Africa
}

\begin{abstract}
This study was examined factors affecting auditors' independence with reference to private audit firms in Ethiopia. The researcher employed quantitative research approach with explanatory research design where the effect caused by the independent variable on the dependent variable is observed through regression analysis. Primary data was collected through structured questionnaire from chive executive officers of private audit firm. Accordingly, the result of regression analysis showed that size of audit firm, size of audit fee, professional audit standard, competition, existence of audit committee and information technology have positive and statistically significant effect on auditors' independence. Whereas, provision was not statistically significant. Based on the findings of the study, the researcher recommended that for audit firms in Ethiopia have to work on statistically significant variables due to fact that they have positive influence in improving auditors' independence.
\end{abstract}

Keywords: Determinants, Auditors' Independence, Private Audit Firms, Ethiopia

DOI: $10.7176 /$ RJFA/12-11-04

Publication date:June $30^{\text {th }} 2021$

\section{Introduction}

The reliable information is produced by independent audit firms for investment decisions. Hence, regulators around the world have agreed that public or private firms must disclose independently audited financial statements. Independence is critically important to an auditor as it is regarded as being one of the fundamental principles underlying the auditor's work. The financial markets, businessess firms and government must have confidence in the integrity and objectivity of auditors and without definite independence, audits have little value (John And Tasie, 2012). Hence, it has a constructive to study the factors affecting independency of audit firms in conducting the auditing activity in Ethiopia. Because, prior researches do not touched the factors affecting auditor's independency of audit firms in Ethiopia and focused on assessment audit practice. Understanding and identifying the factors affecting independence of private audit firm is the corner stone for improving financial reporting quality of business or government entities. Improving the effectiveness of audit firms work quality is possible after identifying and controlling the factors affecting auditor's independence.

Different scholars have been conducted their research on same topic outside Ethiopia. For example, Alleyne et al (2006), Barizah et al (2005); Albeksh (2017); Carren (2013); John and Tasie (2012); Stephen et. al, (2015) and have been conducted the research on similar topic using descriptive statistics for analyzing the data collected through self-administered questionnaire and found out that firm size, professional audit standard, size of audit fees, level of completion, the provision of non-audit service are factors affecting auditor's independence in effectively performing audit work. This study is different from the prior study reviewed above by employing inferential statistics to identify factors affecting independence of auditor's with reference to authorized audit firm in Ethiopia which enhances the reliability of the findings more than that of descriptive statistics used in the above studies. Besides, dissimilar to prior studies, this study incorporated two more explanatory variables such as existence of audit committee and information technology facility in the logit model. On other hand there is difference in geographical scope of prior studies as far as this study has planned to be conducted in Ethiopia and audit practice is different from natation to natation. Furthermore, there is the time gap as far as prior studies outside and in Ethiopia covered time period from 2005 till 2017 but covered the time between 2018 up to 2021G.C.

When it comes to Ethiopia, very few researchers has been conducted their study on the similar topic. For instance, Asmamaw (2018) studied the topic with sample size of 60 audit firms, Adane (2014) used sample size out of 71 firms; and Zergaw (2016) used 88 private audit firms as sample size. The prior studies in Ethiopia employed the time using non-probability sampling technique to select authorized audit firms as sample. The non-probability sampling technique has limitations on the way of generalizing sample finding from sample to the total population. But the researcher employed the probability sampling technique in this study in order to give equal chance for all audit firms in Ethiopia. Also, the researcher have planned to identify the influence of information technology facilities on independence of auditor's in Ethiopia. This study is different by improving sample size to 93 and applying probability sampling technique in order to give equal chance for all audit firms in Ethiopia and to save the resources. Therefore, the objective of this study is to identify the factors affecting auditor's independence with reference to private audit firms operating in Ethiopia by filling the above methodological, variable incorporation, and time research gaps identified through review of studies in Ethiopia 
and outside Ethiopia.

This paper was organized in to six sections. The first part is introduction. The second section reviews different literature that relates to the topics of the study. In the third section the research methodology was addressed. Section 4 covered the results and discussions and finally, section 5 concluded the paper and last section 6 provides direction for the future research.

\section{Literature Review}

\subsection{Concept of Auditor's Independence}

Auditor's independence refers to the independence of the auditors from parties that may have a financial interest in the organization being audited (conduct audit work without interference). The concept of auditor's independence implies that the auditor should carry out his or her work freely and in an objective manner. According to (Langli and Svanström, 2013) auditor's independence enables to produces the quality financial information that helps in making good economic decisions. Generally accepted auditing standards (GAAS) are a set of systematic guidelines used by auditors when conducting audits on companies' financial records, ensuring the accuracy, consistency, and verifiability of auditors' actions and reports. The general standard part two suggests that "the auditor must maintain independence in mental attitude in all matters relating to the audit." Auditor independence refers to the independence of the internal auditor or of the external auditor from parties that may have a financial interest in the business being audited. Independence requires integrity and an objective approach to the audit process. The concept requires the auditor to carry out his or her work freely and in an objective manner.

Independence is the basis of the auditing process because it assists the auditor to express the opinion of the auditor about the financial data in his/her report, without any effects on his/her judgment, his/her duty with honesty, faithfulness and secretariat. Based on the above description, the above factors may pose threats to the audit profession if external auditors deal with it. Organizational independence of private audit firm allows the audit activity to conduct work and be perceived to conduct work without interference (Carcello et al. 2020).

Church et al (2018) studied Auditor Independence in the United States suggested that independence precludes relationships that may appear to impair a member's objectivity in rendering attestation services. For professional accountants in public practice, the maintenance of objectivity and independence requires a continuing assessment of client relationships and public responsibility. Such a professional accountant who provides auditing and other attestation services should be independent in fact and appearance. In providing all other services, a professional accountant should maintain objectivity and avoid conflicts of interest. In other way, objectivity of audit staff or audit firm must have impartial attitudes and avoid any conflict of interest. Objectivity is a key factor for audit activity to add value.

A professional accountant should be fair and should not allow prejudice or bias, conflict of interest or influence of others to override objectivity. A professional accountant should maintain objectivity and be free of conflicts of interest in discharging professional responsibilities. Objectivity is a state of mind, a quality that lends value to a professional accountant's services. It is a distinguishing feature of the profession. The principle of objectivity imposes the obligation to be impartial, intellectually honest, and free of conflicts of interest (Tepalagul \& Lin, 2015).

\subsection{Types of Auditor's Independence}

Based on types of auditors exist in auditing environment, it can be classified as internal auditor and external auditor independency. These are:

a) Independence of the internal auditor means independence from parties whose interests might be harmed by the results of an audit. Specific internal management issues are inadequate risk management, inadequate internal controls, and poor governance. The Charter of Audit and the reporting to an Audit Committee generally provides independence from management, the code of ethics of the company (and of the Internal Audit profession) helps give guidance on independence from suppliers, clients, third parties, etc.

b) Independence of the external auditor means independence from parties that have an interest in the results published in financial statements of an entity. The support from and relation to the Audit Committee of the client company, the contract and the contractual reference to public accounting standards/codes generally provides independence from management, the code of ethics of the Public Accountant profession) helps give guidance on independence from suppliers, clients, third parties (Chepkorir, 2013). This study was focused on determinants of external auditors' independence.

\subsection{Empirical literature Review}

In this study variables has incorporated as independent variable audit firm size, size of audit fee professional audit standard, competition level, provision of non-audit service, audit committee, information technology facility and auditor's independence which is dependent variable. These have been explained in the following 
table:

Table1: Summary of Empirical literature Review

\begin{tabular}{|c|c|c|c|}
\hline Variable name & Empirical studies & $\begin{array}{l}\text { Empirical Results on } \\
\text { effect of each variable } \\
\text { on auditors } \\
\text { 'independence }\end{array}$ & Hypotheses \\
\hline $\begin{array}{l}\text { 1. Audit Firm } \\
\text { Size }\end{array}$ & $\begin{array}{l}\text { Asmamaw (2018); John \&Tasie (2012); } \\
\text { Albeksh, (2017); Carren (2013); } \\
\text { Stephen et. al.(2015); and Chepkorir } \\
\text { ( 2013) }\end{array}$ & $(+)$ & $\begin{array}{l}\text { H1: Size of audit } \\
\text { firm has positive } \\
\text { influence on external } \\
\text { auditors } \\
\text { independence }\end{array}$ \\
\hline $\begin{array}{ll}\text { 2. } & \text { Size of } \\
& \text { Audit Fee }\end{array}$ & $\begin{array}{l}\text { Adane (2014); Abed \& Al-badainah } \\
\text { (2013);Carren (2013);Chepkorir(2013); } \\
\text { Indrasti\&Karlina (2020); and } \\
\text { Asmamaw (2018) }\end{array}$ & $(+)$ & $\begin{array}{l}\text { H2: Increase in size } \\
\text { of audit fee has } \\
\text { positive effect on } \\
\text { auditors } \\
\text { independence }\end{array}$ \\
\hline $\begin{array}{l}\text { 3. } \\
\text { Professional } \\
\text { Audit } \\
\text { Standards }\end{array}$ & $\begin{array}{l}\text { IIA (2014); Langli and Svanström } \\
\text { (2013); Muluneh (2007); Rusmanto } \\
\text { (2012); Salawu (2017) and Setiawan et } \\
\text { al (2020). }\end{array}$ & $(+)$ & $\begin{array}{l}\text { H3: Existence of } \\
\text { professional audit } \\
\text { standard has positive } \\
\text { effect on auditors } \\
\text { independence }\end{array}$ \\
\hline $\begin{array}{ll}\text { 4. } & \text { Level of } \\
\text { Competitio } \\
\mathrm{n}\end{array}$ & $\begin{array}{l}\text { Xie (2016); Gul (2007); Wubishet and } \\
\text { Dereje (2018); Zergaw(2016 ); John } \\
\text { And Tasie (2012); Rusmanto (2012); } \\
\text { Muturi et al. (2015), Indrasti \& Karlina } \\
\text { (2020; Dewantoro(2016);Albeksh } \\
\text { (2017); Asmamaw (2018) }\end{array}$ & $(+)$ & $\begin{array}{l}\text { H4: Increase level of } \\
\text { competition in audit } \\
\text { market has positive } \\
\text { influence on } \\
\text { independence of } \\
\text { auditors. }\end{array}$ \\
\hline $\begin{array}{ll}\text { 5. } & \text { Provision of } \\
\text { Non-Audit } \\
\text { Service }\end{array}$ & $\begin{array}{l}\text { Salehi (2009); John And Tasie (2012); } \\
\text { Abed\& Al-badainah (2013); Habib } \\
\text { (2012); Hohenfels \& Quick (2018); } \\
\text { Kang et al (2018); Tansuria (2020); and } \\
\text { Titus et al. (2014) }\end{array}$ & $(-)$ & $\begin{array}{l}\text { H5: Provision of no } \\
\text { audit service has } \\
\text { negative effect on } \\
\text { external auditor's } \\
\text { independence }\end{array}$ \\
\hline $\begin{array}{ll}\text { 6. } & \text { Audit } \\
& \text { Committee }\end{array}$ & $\begin{array}{l}\text { Teoh \& Lim (1996); Carren, (2013); } \\
\text { Ashari \& Krismiaji (2020); Alderman } \\
\text { \& Jollineau (2020); Widiatami et al. } \\
\text { (2020); }\end{array}$ & $(+)$ & $\begin{array}{l}\text { H6: The existance of } \\
\text { audit committe has } \\
\text { positive effect on } \\
\text { independence of } \\
\text { auditors. }\end{array}$ \\
\hline $\begin{array}{ll}\text { 7. Information } \\
\text { technology }\end{array}$ & $\begin{array}{l}\text { Soltan (2007); Romadhina (2016); } \\
\text { Biduri. (2018); Santy Setiawan et } \\
\text { al.,(2020) }\end{array}$ & $(+)$ & $\begin{array}{l}\text { H7: Information } \\
\text { tecnology has } \\
\text { positive effect on } \\
\text { auditor's } \\
\text { independence }\end{array}$ \\
\hline
\end{tabular}

Source: Own built (2021)

\subsection{Conceptual Fframework of the Sstudy}

This section provides a conceptual frame work for this study based on literature review. It explains the relationships among dependent and independent variables. In this model variables such as audit firm size (AFS), Audit fee (AF), Professional audit standard (PAS), Competition level (CL), provision of non-audit service (NAS), Audit committee (AC), Information technology facility (ITF) and independency of auditor's (IA) which is dependent variable. 


\section{Figure 1: Conceptual Framework}

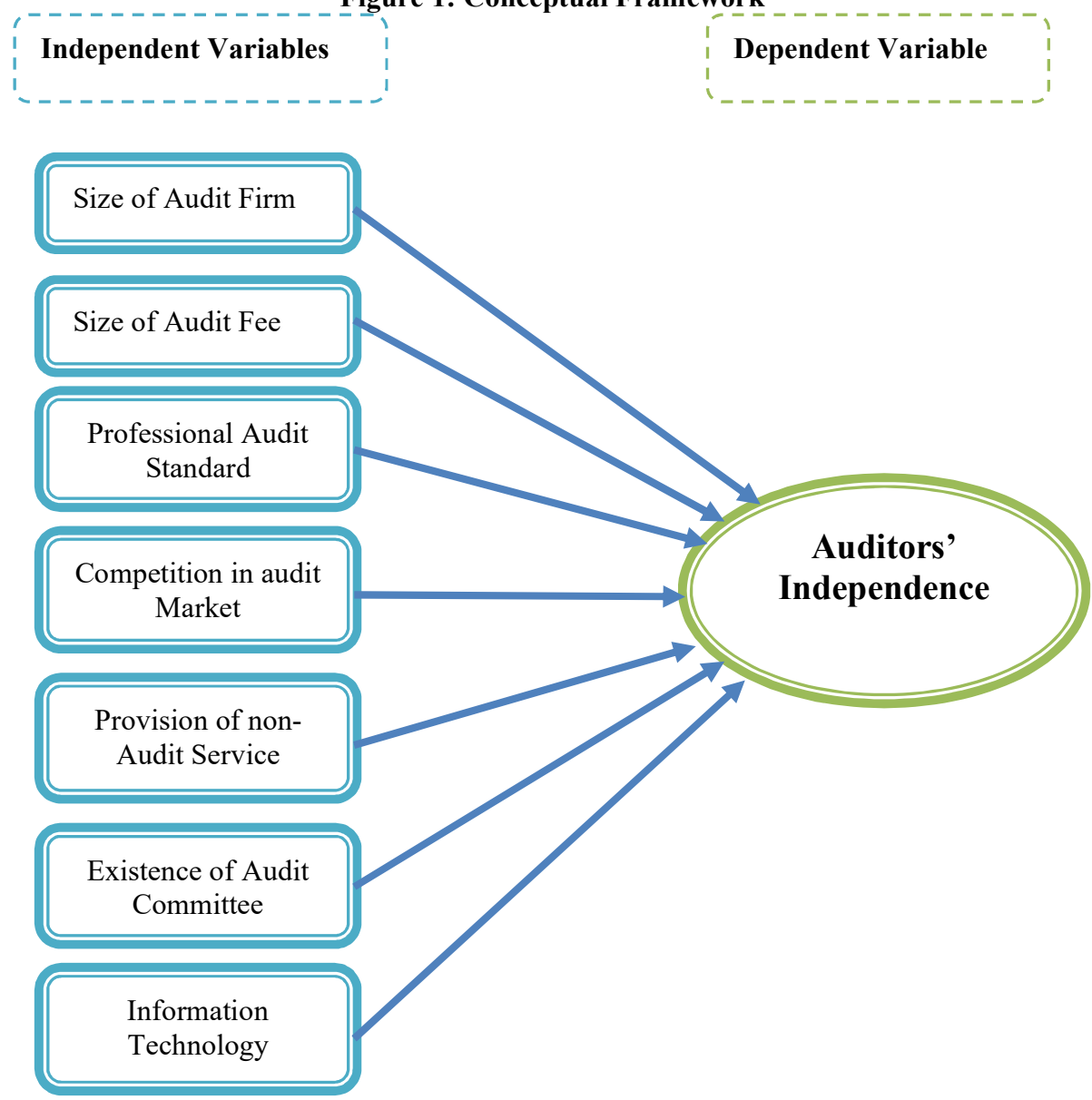

Source: Researcher's own model (2021)

\subsection{Research Gaps}

As per literature review of both studies outside and inside Ethiopia, most the above reviewed studies has focused on particular firms or regions of the nation but the current study focused on the factors affecting external auditor's independence in Ethiopia and also selected respondents using probability in opposing to the sample size selection which non- probability for most studies reviewed above. Besides, studies outside Ethiopia has no empirical models in explaining the relationship between explanatory variables and dependent variables incorporated in their study. As a result, conducting this research would add value for the government of Ethiopia, business firms, and audit firms in Ethiopian by identifying the factors determining external auditors' independence with reference to audit firms in Ethiopia by filling the above mentioned gaps that enables concerned bodies to improve quality of information reported by private or public firms in Ethiopia.

\section{Methodology}

\subsection{Research Design \& Approach}

In this study, the mixed research approach was employed. The justification for combining both quantitative and qualitative data is to better understand since the research problem by combining both numeric values from quantitative research and the qualitative research and to nullify limitations of applying any of a single approach. A research design is the arrangement of conditions for collection and analysis of data in a manner that aims to combine relevance to the research purpose with economy in procedure. When the purpose of research is to test a research hypothesis, it is termed as hypothesis-testing research. These factors affect auditor's independence firms in Ethiopia. To do this, the methods that employed explanatory research design which enables to explain the relationship between seven independent variables such as audit firm size, audit fee size, audit standards, competition, provision of non-audit service, information technology and one dependent variable auditor's. In addition, survey research design was used as it enables for gathering information through self-administered questionnaires or interviews from CEO of private audit firms in Ethiopia independence. 


\subsection{Data Type and tools of data collection}

Data types the student researcher used were both primary and secondary. Primary data were collected directly from the respondents by distributing questionnaires. Whereas, secondary data were gathered from reports, bulletins, journals, text books and documents of the study organization. To collect primary data structured questionnaires was used. And secondary data was collected through review of different published and unpublished materials that related to topic.

\subsection{Target Population, Sampling Technique and Size Determination}

Target Population: According to (AABE, 2021) there are 157 private audit firms in Ethiopia. Hence, the target population of this study is one hundred twenty one (157) Authorized Auditors in Ethiopia.

Sampling Technique: Sample is the section of the total population. For successfully, conducting this study, the researcher used simple random sampling to select 122 private audit firms from 157 total authorized firms. The researcher employed simple random sampling technique in order to give equal chance for all audit firms and to save the resources.

Size Determination: In order to scientifically determining the sample, the sample size formula of (Yamane, 1967) was used by the researcher. This sample size considers that sample selected from the pupulation repersents $95 \%$ of the population. Hence, sample size is determined by using formula indicated below:

$$
\begin{gathered}
\boldsymbol{u}=\frac{N}{1+(\boldsymbol{e}) 2 * \mathrm{~N}} \\
\text { Where: } \mathrm{n}=\text { sample size } \\
\mathrm{N}=\text { population size } \\
\mathrm{e}=\text { Precision level or sampling error }=0.05 \\
n=\frac{157}{1+(0.05) 2 * 157}=122
\end{gathered}
$$

Hence, the representative sample size for this study is 122 private audit firm chive Executives officers. Methods of Data Collections

3.4 Operational Definition of variables

Table 1: Summary of variables Definition and Scale of Measurement

\begin{tabular}{|l|l|l|}
\hline Variables incorporated & $\begin{array}{l}\text { Sym } \\
\text { bol }\end{array}$ & $\begin{array}{l}\text { Unit of } \\
\text { measuremen } \\
\text { t }\end{array}$ \\
\hline $\begin{array}{l}\text { Auditor's Independence: Freedom of auditor to carry out his or her work freely and in } \\
\text { an objective manner. }\end{array}$ & IA & $\begin{array}{l}5 \text { point Likert } \\
\text { scale }\end{array}$ \\
\hline $\begin{array}{l}\text { Size of audit firm: revenue earing capacity or wealth capacity due long term } \\
\text { experience in audit work. }\end{array}$ & AFZ & $\begin{array}{l}5 \text { point Likert } \\
\text { scale }\end{array}$ \\
\hline $\begin{array}{l}\text { Size Audit fee: audit Fees are costs incurred by companies to pay public accounting } \\
\text { firms to audit the company's financial statements }\end{array}$ & SAF & $\begin{array}{l}5 \text { point Likert } \\
\text { scale }\end{array}$ \\
\hline $\begin{array}{l}\text { Professional audit Standard: are a set of systematic guidelines used by auditors when } \\
\text { conducting audits on companies' financial records }\end{array}$ & PAS & $\begin{array}{l}5 \text { point Likert } \\
\text { scale }\end{array}$ \\
\hline $\begin{array}{l}\text { Competition level: competition in audit market } \\
\text { Provision of non-audit service: Non-audit services are any services other than } \\
\text { statutory audit services and typically comprise: }\end{array}$ & CL & $\begin{array}{l}5 \text { point Likert } \\
\text { scale }\end{array}$ \\
\hline $\begin{array}{l}\text { Audit committee: number of members of a company's board of directors whose } \\
\text { responsibilities include helping the auditors remain independent of management }\end{array}$ & $\begin{array}{l}5 \text { point Likert } \\
\text { scale }\end{array}$ & $\begin{array}{l}5 \text { point Likert } \\
\text { scale }\end{array}$ \\
\hline $\begin{array}{l}\text { Information Technology: Information technology facilities that are base for } \\
\text { conducting audit activities }\end{array}$ & $\begin{array}{l}5 \text { point Likert } \\
\text { scale }\end{array}$ \\
\hline
\end{tabular}

Source: Own build (2019)

\subsection{Econometrics Model Specification}

When it comes to model specification, auditors' independence in conducting audit work without interference of others is a dependent variable of this study, while seven variables such as audit firm size (SAF), size of Audit fee (AFS), Professional audit standards (PAS), competition in audit service market (CL), provision of non-audit service (NAS), audit committee (AC) and Information technology (IT) are independent variables. In this study, the dependent variable is measured through five point Likert scale and considered as continuous variable. For the continuous variables multiple linear regression is best model. The equation is expressed as follow: 


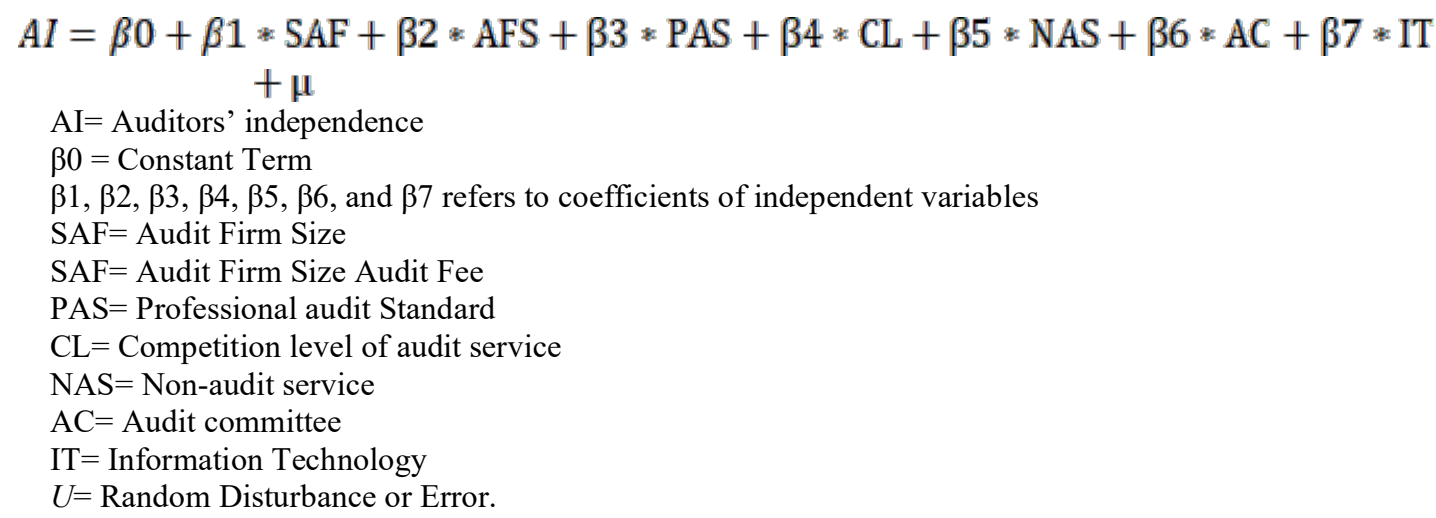

\subsection{Assumptions of Classical Linear Regression Model}

The following diagnostic tests were carried out to ensure that the suits the basic assumption of classical linear model. Among the assumption, the researcher conducted four basic diagnostic tests to check if the data meet the requirement. Normality, Multicollinearity, autocorrelation, and heteroscedasticity tests were undertaken.

\subsection{Methods of Data Analysis}

After accomplishment of data collection procedure, it should have classified as per each variable, the qualitative data has been coded to be measured quantitatively. In this research, data has been analyzed by using descriptive statistics such as maximum and minimum values, average, correlation, frequency, percentage, variance and standard deviation and inferential statistics (binary logistic regression model) through SPSS version 21.0 in order to get the reliable finding.

\subsection{Reliability of the Test}

The test of reliability is another important test of sound measurement of questionnaire. To measure the consistency of the questionnaire particularly the Likert-type scale the reliability analysis is essential in reflecting the overall reliability of constructs that it is measuring. In current research, the researcher employed Cronbach's Alpha $(\alpha)$ which is the most common measure of scale reliability and a value greater than 0.7 is very acceptable. This has tested as follow:

Table 3: Reliability Test of the variables

\begin{tabular}{|c|c|}
\hline Cronbach's Alpha & N of Items \\
\hline 0.889 & 34 \\
\hline
\end{tabular}

Source: Personal survey, 2021

This indicates that all the variables under consideration accounts above the scientifically accepted threshold, therefore the study are reliable under this circumstance. compared with the minimum value of alpha 0.70 advocated by Cronbach's (1951), then the responses generated for all of the variables 'used in this research were reliable enough for data analysis. This implies that the data incorporated in SPSS is reliable.

\subsection{Ethical Considerations}

The ethical considerations like voluntary participation, no harm to participants, anonymity and confidentiality, not deceiving the subjects and privacy of participants have been given attention by the researchers and enumerators while conducting the research that includes.

\section{Results And Discussion}

This section is deals with analysis and discussion of data collected from 80 respondents out of 122 sample respondents from selected audit firms in Ethiopia. The response rate was $65 \%$ which implies more than $50 \%$ respondents have been participated in the process of data collection. Then, the analysis of the data was based on the questionnaires collected using SPSS version 21.0. The first section of the analysis concerns about descriptive statistics, correlation analysis and regression analysis. 
4.1 Descriptive Statistics

Table 4: Summary of Descriptive Statistics for all Variables Incorporated in the Model

\begin{tabular}{|l|l|l|l|l|l|}
\hline Variables & $\mathrm{N}$ & Minimum & Maximum & Mean & Std. Deviation \\
\hline Independence of Auditors & 80 & 1.00 & 5.00 & 2.8875 & 1.19061 \\
\hline The sizes of audit Firm & 80 & 1.00 & 5.00 & 2.8375 & 1.31634 \\
\hline Size of Audit fee & 80 & 1.00 & 5.00 & 3.1625 & 1.32592 \\
\hline Professional Audit standard & 80 & 1.00 & 5.00 & 3.1500 & 1.04458 \\
\hline Level of competition in audit market & 80 & 1.00 & 5.00 & 2.7125 & 1.14950 \\
\hline Performance of non-audit service & 80 & 1.00 & 5.00 & 2.9969 & .76897 \\
\hline Audit committee & 80 & 1.00 & 5.00 & 3.2365 & .98112 \\
\hline Information technology & 80 & 1.00 & 5.00 & 3.0000 & .94132 \\
\hline
\end{tabular}

Sources: Personal survey, 2021

Independence of Auditors was the dependent variable of this study. As indicated in the above table 4, the audit firms in Ethiopia achieved on average positive auditor independence because the overall mean was 2.8875. The standard deviation value is 1.19061 which indicates there was variation of actual responses from the mean. This implies that audit firms need to improve the independence of auditors to high level in order to protect public interest. With regard to the sizes of audit firm, the overall mean was 2.8375 and SD of 1.31634 . The mean of the size of audit fee was 3.1625 with standard deviation of 1.32592, the average value for professional audit standards as measured by five point Likert was 3.1500 with standard deviation is 1.04458 , the mean of the examination process was 2.7125 with SD of 1.14950, the performance of non- audit service has mean of was 2.9969 and standard deviation 0.76897 , the average value of the audit committee was 3.2365 followed by standard deviation value of 0.98112 and, information technology with mean value 3.0000 with standard deviation of score from mean value is 0.94132 . In summary, all variables incorporated in the model have low and moderate contribution to the response variable auditors' independence.

\subsection{Pearson Correlation Matrix}

Correlation analysis measures the relationship between two items. The correlation matrix for this study was computed as follow.

Table 5: Pearson Correlation Matrix for Variables

\begin{tabular}{|l|l|l|l|l|l|l|l|l|}
\hline Variable & AI & SAF & SAF & PAS & LC & PNA & AC & IT \\
\hline AI & 1 & & & & & & & \\
\hline SAF & $.352^{* *}$ & 1 & & & & & & \\
\hline SAF & $.132^{*}$ & $-.456^{* *}$ & 1 & & & & & \\
\hline PAS & $.268^{*}$ & .147 & .019 & 1 & & & & \\
\hline LC & $.309 *$ & -.073 & .272 & -.132 & 1 & & & \\
\hline PNA & .121 & .036 & -.182 & -.129 & .051 & 1 & & \\
\hline AC & $.336^{* *}$ & .059 & .050 & .049 & .144 & $.266^{* *}$ & 1 & \\
\hline IT & $.237^{*}$ & .286 & -.020 & .154 & -.304 & -.143 & .075 & 1 \\
\hline
\end{tabular}

Sources: Personal survey, 2021

**Correlation is significant at $1 \%$ significance level, $*$ Correlation is significant at $5 \%$ significance level (two tailed).

The table 5 shows the relationship between dependent variable which is auditors' independence (AI) and independent variables with coefficient of correlation 1 indicates that each variable is perfectly correlated with each other. The result shows that, size of audit firm (SAF), competition (LC), audit committee (AC), were positively correlated and at $1 \%$ significance level (as $\mathrm{P}<0.01)$ with independence of auditors (AI). Whereas, variables such as professional audit standard (PAS), size of audit fee and information technology (IT) were positively correlated with auditors' independence and statistically significant at $5 \%$ level of significance for the reason their $\mathrm{P}<0.05$. The performance of non-audit service has positive relationship with auditors but statistically insignificant respectively since p-value is more than $1 \%$ and $5 \%$ levels of significance. The result shows the acceptable reliability of the research variables in which, the correlation among predictors were not high and more than 0.80 indicates there are no multicollinearity problems among variables which are best for analysis of the data for this study.

\subsection{Test of Ordinary Least Square Assumptions}

The classical linear regression model assumptions such as such as normality, heteroscedasticity, multicollinearity and autocorrelation have been conducted before regression analysis. Therefore, it can be concluded that there is no normality, heteroscedasticity, multicollinearity and autocorrelation problems that cause regression results of the model to be biased. 
4.3 The Regression Results (Inferential Statistics)

Table 7: Regression Results through SPSS

$\mathrm{R}=0.674 \mathrm{a}, \mathrm{R} 2=0.455$, Adj. R2 $=0.402$,Std. Error of the Estimate $=0.92091$, Durbin-Watson $(\mathrm{d})=1.887, \quad \mathrm{~F}-$ statistic $=8.578$, P-value $=0.000$, ANOVA with (p-value of 0.000

\begin{tabular}{|c|c|c|c|c|c|c|c|c|c|c|}
\hline \multirow{2}{*}{\multicolumn{2}{|c|}{ Model }} & \multicolumn{2}{|c|}{$\begin{array}{l}\text { Unstandardized } \\
\text { Coefficients }\end{array}$} & \multirow{2}{*}{$\begin{array}{l}\text { Standardized } \\
\text { Coefficients } \\
\text { Beta }\end{array}$} & \multirow[t]{2}{*}{$\mathrm{t}$} & \multirow[t]{2}{*}{ Sig. } & \multicolumn{2}{|c|}{$\begin{array}{l}95.0 \% \text { Confidence } \\
\text { Interval for B }\end{array}$} & \multicolumn{2}{|c|}{$\begin{array}{l}\text { Collinearity } \\
\text { Statistics }\end{array}$} \\
\hline & & B & $\begin{array}{l}\text { Std. } \\
\text { Error }\end{array}$ & & & & $\begin{array}{l}\text { Lower } \\
\text { Bound }\end{array}$ & $\begin{array}{l}\text { Upper } \\
\text { Bound }\end{array}$ & Tolerance & VIF \\
\hline 1 & (Constant) & -2.676 & .836 & & $-\overline{3.200}$ & .002 & -4.344 & -1.009 & & \\
\hline & SAF & .334 & .096 & .369 & 3.492 & $.001 * *$ & .143 & .525 & .676 & 1.479 \\
\hline & SAF & .203 & .096 & .226 & 2.112 & $.038 *$ & .011 & .394 & .664 & 1.506 \\
\hline & PAS & .263 & .103 & .231 & 2.550 & $.013 *$ & .057 & .468 & .927 & 1.079 \\
\hline & LC & .346 & .102 & .334 & 3.380 & $.001 * *$ & .142 & .549 & .777 & 1.286 \\
\hline & PNA & .224 & .151 & .140 & 1.481 & .143 & -.078 & .525 & .849 & 1.177 \\
\hline & $\mathrm{AC}$ & .231 & .113 & .191 & 2.049 & $.044 *$ & .006 & .456 & .874 & 1.144 \\
\hline & IT & .263 & .126 & .208 & 2.092 & $.040 *$ & .012 & .513 & .769 & 1.301 \\
\hline
\end{tabular}

Dependent Variable: Auditors' Independence (AI), N=80

$* *$ is Significant at $1 \%$ significance level, * is significant at $5 \%$ significance level

Sources: Personal survey, 2021

Fitted Model

$\mathrm{AI}=-2.676+0.334 * \mathrm{SAF}+.203 * \mathrm{SAF} 0.263 * \mathrm{PAS}+0.346 * \mathrm{CL}+0.224 * \mathrm{PNA}+.231 * \mathrm{AC}+0.263 * \mathrm{IT}$

The OLS result of was presented in the above table 7. R-squared was measured the goodness of fit of the explanatory variables in explaining the variations in independence of auditors' in Ethiopia. R-squared and the Adjusted-R- squared statistics of the model were 45.5 percent and 40.2 percent respectively. The result indicates that 40.2 percent variation in the dependent variable was explained by the explanatory variables in the model. That means the explanatory variables (such as size of audit firm (SAF), size of audit fee (SAF), professional audit standard (PNA), completion level $(\mathrm{Cl})$, profession of non-audit service (PNA), audit committee (AC), and Information technology (IT) are jointly explain about 40.2 percent of the variation in the auditor's independence. The remaining 49.8 percent of the variation in the auditor independence (as measured by Likert scale) explained by other variables which are not included in the model. Even if the result is lower than $50 \%$, it is acceptable for social science. Because, According to (Peterson, 2016), a high R-square or adjusted R- Square of above $60 \%(0.60)$ is required for studies in the 'pure science' field because the behavior of molecules and/or particles can be reasonably predicted to some degree of accuracy in science research; while an R-square or adjusted R- Square as low as $10 \%$ is generally accepted for studies in the field of arts, humanities and social sciences because human behavior cannot be accurately predicted, therefore, a low R-square is often not a problem in studies in the arts, humanities and social science field.

Besides, the, F- statistics (8.578) in model summary and ANOVA with (p-value of 0.000) which is used to test the overall significance of the model was presented and indicates the reliability and validity of the model at 1 percent level of significance. This tells us that the model as a whole is statistically significant for more information. The coefficients of audit firm size 0.334 , audit fee 0.203 , professional audit standard 0.263 , competition 0.346 , performance of non-audit service 0.224 , audit committee 0.231 and information technology is 0.263 is leads to positive direction dependent variable respectively.

\section{Discussion of the results}

Size of Audit Firm: result of this study shows that size of audit firm with coefficient of regression $[\beta=0.334]$ has positive and statistically significant at $1 \%$ level of significance since (p-value of $0.001<0.01$ ). Hence, hypothesis H1 is accepted. This finding is consistent the finding of other studies results of Asmamaw (2018); John \&Tasie (2012); Albeksh, (2017); Carren (2013); Stephen et al (2015); and Chepkorir ( 2013) who found out that the size of audit firm has positive influence on independence of audit firm. The regression result of the model regarding size audit firm was also clearly evidenced that there is statistically significant and positive relationship between independence sizes of audit firm as far as the sign of unstandardized coefficient of regression is positive. This implies that more independence the auditors unit positively contributes to the usefulness of accounting information.

Size of Audit Fee: the result of this study with regards to size of audit fee coefficient of regression $[\beta=0$. 203 ] has positive and statistically significant at $5 \%$ level of significance since ( $p$-value of $0.038<0.05)$. Hence, the researcher forced to accept hypothesis H2. This finding is consistent the finding of other studies results Adane (2014); Abed \& Al-badainah (2013);Carren (2013);Chepkorir(2013); Indrasti\&Karlina (2020); and Asmamaw (2018) who found out the positive and significant relationship between size of audit fee and auditor's 
independence. The regression result of the model regarding the variable was also clearly evidenced that there is statistically significant and positive relationship between audit fee size and independence as far as the sign of coefficient of regression is positive.

Professional Audit Coefficient: regarding to the professional audit coefficient of regression of professional audit standard of $[\beta=0.263]$ is positive and more statistically significant with $p$-value $(0.013<5 \%$, level of significance. Therefore, hypothesis $\mathrm{H} 3$ stated as is accepted by the researcher. This finding is consistent with that of IIA (2014); Langli and Svanström (2013); Muluneh (2007); Rusmanto (2012); Salawu (2017); Setiawan et al (2020); Kirima (2016), Shewamene, 2014) and (Tesema, 2018) who found out that professional standards has positive and significant effect on auditor's independence. This indicates existence of professional audit standards has positive influence on independence of auditor's.

Competition Level: when comes to the competition level with unstandardized coefficient of regression of $[\beta=0.346]$ is positive and more statistically significant with $p$-value $(0.001<1 \%$, level of significance. Therefore, hypothesis H4 stated is accepted. This finding is consistent with that of Xie (2016); Gul (2007); Wubishet and Dereje (2018); Zergaw (2016); John \& Tasie (2012); Rusmanto (2012); Muturi et al. (2015), Indrasti \& Karlina (2020; Dewantoro (2016); Albeksh (2017); and Asmamaw (2018) found out that competition has positive and significant relationship with public good governance. This indicates increase in competition in audit market has positive influence on auditor's independence.

Performance of Non-Audit Service: the result of this study also shows that performance of non-audit service with unstandardized coefficient of regression $[\beta=0.224]$ has positive and statistically insignificant since ( $p$ value of $0.143>0.01$ and 0.05 ) Hence, hypothesis H5 is not accepted. This finding is inconsistent with finding of other studies results (John And Tasie, 2012; Barizah et. al., 2005; Kang et. al., 2018; Salehi, 2009) providing non-audit service by external auditors to the same clients strongly negatively affect to audit independence.

Audit Committee: with regarding to audit committee regression coefficient was $[\beta=0.231]$ is positive and statistically insignificant with p-value $(0.044<5 \%$ level of significance. Therefore, hypothesis H6 is accepted. Result is similar with study finding of empirical researches such as Teoh \& Lim (1996); Carren (2013); Ashari \& Krismiaji (2020); Alderman \& Jollineau (2020); and Widiatami et al (2020) concluded that the development of audit committees has a strong positive effect on auditor independence. This indicates that in existence of audit committee in has constructive influence on auditor's independence.

Information Technology: the result of this study shows that information technology with coefficient of regression $[\beta=0.263]$ has positive and statistically insignificant since (p-value of $0.040<5 \%$, level of significances. Hence, hypothesis $\mathrm{H} 7$ was accepted by researcher. This finding is consistent with research finding of Soltan (2007); Romadhina (2016); Biduri. (2018); Santy Setiawan et al, (2020) Al-Refaee and Ahmad (2013); (Soltan 2007); Shilla (2014) and Farida et al (2018) suggested that information technology has positive and statistically significant effect independence of external auditors. The finding implies that increase in information technology facility has positive effect on auditor's independence.

\section{Conclusions}

Conclusion is the process of making generalization based on findings of sample to total study population. Therefore, the findings revealed from this study were generalized to all audit firms in Ethiopia. In this research work, the researcher explored factors affecting auditors, independence. By keeping this objective in mind, the researcher collected the primary data through self-administrated and questionnaire developed in the form of Likert scale. By using SPSS version 21.0, the analysis of both descriptive and inferential statistics has been done. Based on the findings from the regression analysis of the model, the researchers concluded that the auditors' independence was best explained by the explanatory variables included in the model. The study has shown a clear understanding of factors influencing auditors' independence in Ethiopia. The finding of this research demonstrated that the audit firm size, size of audit fee, professional audit standard, level of competition, existence of audit committee and information technology have statistically significant and positive influence on the auditors independence in Ethiopia. As the result hypotheses H1; H2; H3; H4; H6 and H7 were accepted by researcher. But hypotheses five (H5) was rejected by researcher.

\section{Future Research directions}

Since any study cannot be free from limitations, accordingly there are some limitations in current study. In the beginning, it focused only on identifying the factors affecting auditor's independence in Ethiopia. The seven explanatory variables incorporated in the model have only explained $40.2 \%$ of the model. The remaining $49.8 \%$ of changes in the independence of external auditors was explained by other explanatory variables that not included in the model. The other researcher should incorporate more variables to improve adjusted $\mathrm{R}^{2}$ with the same topic at the same study area. In other way, the findings of this study may be difficult to generalize about all nations in all world. Hence, this study can be improved if it will be done at other nations and at international national level by comparing independence of auditors of public sector organizations with private organizations. 


\section{Acknowledgements}

I am very honorable to appreciate Dilla University is the best education and research institutions in Ethiopia that striving to serve the community and supporting problem solving researches thoroughly. My pleasant thanks also go to the editors and the anonymous reviewers for their guidance in developing this research paper.

\section{References}

AABE. (2021). List of Registered Certified Audit Firms Exist in Ethiopia in 2013 E.C. Addis Ababa, Ethiopia. http://www.aabe.gov.et. Accessed on February 20, 2021 G. C.

Abed, S., \& Al-badainah, J. (2013). The Impact of Auditor's Gender on Audit Fees: Case of Jordanian Auditors. International Journal of Biometrics, 8, 127.

Adane wudu. (2014). Auditor responsibility and fraud detection: In Ethiopian private audit firms MSC thesis

Albeksh, H. M. (2017). factors affecting the independence of the external auditor within the auditing profession: Available at: www.researchpublish.com . International Journal of Management and Commerce Innovations, 680-689.

Alderman, J., \& Jollineau, S.J. (2020). Can Audit Committee Expertise Increase External Auditors' Litigation Risk? The Moderating Effect of Audit Committee Independence. Contemporary Accounting Research, 37, 717-740.

Alleyne, P.A. Devonish.D. and Alleyne.P. (2006). Perceptions of auditor independence in Barbados. Managerial Auditing Journal Emerald Group Publishing Limited DOI 10.1108/02686900610674898. , pp. 621-635.

American Institute of Accountants, "Certified public Accountant, 1947" (1947). Newsletters. 81. https://egrove.olemiss.edu/aicpa_news/81

Asmamaw Fasika. (2018). Factors Affecting Perceptions of Private Audit Quality: The Case of Amhara Region A Research for the Partial Fulfillment of the Requirements for the Degree of Master of Accounting and Auditing 1-65. BAHIR DAR..

Ashari, S., \& Krismiaji, K. (2020). Audit Committee Characteristics and Financial Performance: Indonesian Evidence.

Barizah Abu Bakar, N., Rahim Abdul Rahman, A. and Majdi Abdul Rashid, H. . (2005). "Factors influencing auditor independence: Malaysian loan officers' perceptions. Managerial Auditing Journal, Vol. 20 No. 8, https://doi.org/10.1108/02686900510, 804-822.

Biduri, S. (2018). The effect of electronic information technology systems, auditor competence, and auditor independence, on ethics moderated auditing quality (empirical study on certified public accountant (cpa) firms in surabaya and sidoarjo).

Carren, C. (2013). Factors Influencing Auditor's Independence and Accountability: A Case Study of Ktda Affiliated Tea Factories in Bomet and Kericho County, Kenya. A Research Project Submitted To School Of Business and Economics In Partial Fulfillment For. Bomet and Kericho .

Chepkorir. ( 2013). Factors Influencing Auditor's Independence And Account-ability, A Case Study of KTDA Affiliated Tea Factories In BOMET and KERICHO County, KENYA. a research project submitted to school of business and economics in partial fulfillmen. Nirobi.

Carcello, J.V., Neal, T.L., Reid, L., \& Shipman, J.E. (2020). Auditor Independence and Fair Value Accounting: An Examination of Nonaudit Fees and Goodwill Impairments. Contemporary Accounting Research, 37, 189-217.

Church, B.K., Jenkins, J.G., \& Stanley, J.D. (2018). Auditor Independence in the United States: Cornerstone of the Profession or Thorn in Our Side? Accounting Horizons, 32, 145-168.

Creswell, J W . (2003). Research design: qualitative, quantitative and mixed methods approaches, 2nd ed., . California: Sage Publications, .

Dewantoro, W.P. (2016). Factors Affecting Tax Auditor Independence (Empirical Study of the Madya Tax Service Office of Malang).

Fleur C. Khalil, Rita G. Yammine . (2019). Impact of Audit Quality on Earnings Management: Case of Lebanon. International Journal of Advanced Trends in Computer Science and Engineering, 35-41.

Fleur C. Khalil, Rita G. Yammine . (2019). Impact of Audit Quality on Earnings Management: Case of Lebanon. International Journal of Advanced Trends in Computer Science and Engineering, 35-41.

Gul, F. A., Qiu, A. and Kim, J. (2007): Political economy, client importance and auditor independence: some evidence from Chinese non-big 4 auditors; March. Available at SSRN

Habib, A. (2012). Non-Audit Service Fees and Financial Reporting Quality: A Meta-Analysis. Abacus, 48, $214-$ 248.

Indrasti, A.W., \& Karlina, B. (2020). Determinants Affecting the Auditor's Ability of Fraud Detection: Internal and External Factors (Empirical Study at the Public Accounting Firm in Tangerang and South Jakarta Region in 2019). 
John Christian Langli and Tobias Svanström . (2013). Audits of private firms. Working Paper. Centre for Corporate Governance Research, 1-40.

John Christian Langli and Tobias Svanström . (2013). Audits of private firms. Working Paper. Centre for Corporate Governance Research, 1-40.

Kirima N. (2016). Factors Affecting The Performance of The Internal Audit Function In Government Ministries In Kenya: A Research Project Submitted To The Chandaria School Of Business In Partial Fulfillment Of The Requirement For The Degree Of Masters In B.

Lukas Beyashe. (2008). Challenges Faced by Ethiopian Federal Government Auditors: the Case of the Office of the Federal Auditor General: A research project paper submitted for the partial fulfillment of M.Sc. Degree in Accounting and Finance. Addis Ababa.

Muluneh Beyene. (2007). "Auditors Professional Responsibilities and Legal Liability with Regard to Private Auditors in Ethiopia": For the Fulfillment of M.Sc Program in Accounting and Finance, Addis Ababa University, School of Gr. Addis Ababa: Muluneh Beyene .

Muturi, D.W., Kabiru, J.M., \& Kenyatta, J. (2015). Factors Affecting External Auditors' Independence In Discharging Their Responsibilities : A Survey Of Medium Level Auditing Firms In Nairobi.

Rusmanto, T. (2012). The Auditors' Perceptions of Small-Medium Audit Firms on Independence.

Romadhina, A.E. (2016). Expertise, Independence and Professional Skills Of Internal Auditors In Preventing Fraud On E-Commerce Transactions (A Case Study At Pt Kereta Api Indonesia). Asia Pasific Fraud Journal. 1(2). 337-350

Peterson .(2016). Answer for what should be minimum value of R-square and adjusted r-square? Available online athttps://www.researchgate.net/post/what_is_the_acceptable_r- squared_value browsed on February 20,2021

Philmore Alvin Alleyne, Dwayne Devonish and Peter Alleyne. (2006). Perceptions of auditor independence in Barbados. . Managerial Auditing Journal Emerald Group Publishing Limited DOI 10.1108/02686900610674898. , pp. 621-635.

S.M. Kang, I. H. (2018). Non-audit Services and Auditor Independence Depending. Australian Accounting Review No. 00 Vol. 00 Issue 0 2018, 1-17.

Salawu, M. K. (2017). Assessment of the Institutional Regulatory Framework of Auditor Independence in Nigeria. African Research Review. AN INTERNATIONAL MULTI-DISCIPLINARY JOURNAL, ETHIOPIA DOI : http://dx.doi.org/10.4314/afrrev.v11i2.9., 108-119.

Saleli, M. (2009). Non-Audit Service and Audit Independence: Evidences from Iran. International journal of business and mangagement, 142-152.

Stephen K. Asare , Arnie Wright \& Mark F. Zimbelman. (2015). Challenges Facing Auditors in Detecting Financial Statement Fraud: Insights from Fraud Investigations . Journal of Forensic and Investigative Accounting, 63-112.

Setiawan, S., Carolina, Y., \& Maranatha, K. (2020). The Effect Of Auditor's Competence And Independence On Information System Audit Quality. Asia Pacific Fraud Journal. 5(2). 183-190. 10.21532/apfjournal.v5i2.155

Tansuria, B.I. (2020). Non-Audit Service Provision and Its Effect on Auditors' Independence and Audit Quality. International Journal of Academic Research in Accounting, Finance and Management Sciences, 10.

Tepalagul, N., \& Lin, L. (2015). Auditor Independence and Audit Quality. Journal of Accounting, Auditing \& Finance, 30, $101-121$.

Teoh, H.Y., \& Lim, C.C. (1996). An empirical study of the effects of audit committees, disclosure of nonaudit fees andother issues on audit independence: Malaysian evidence. Journal of International Accounting, Auditing and Taxation, 5(2), 231-248.

Titus, M., Muturl, W., \& Kabiru, J. . (2014). Factors affecting external auditors ${ }^{\text {ee }}$ independence in discharging their responsibilities: A study of medium level auditing firms in Nairobi. . International Journal of Business \& Law Research, 22-35.

Widiatami, A.K., Tanzil, N.D., Irawadi, C., \& Nurkhin, A. (2020). Audit Committee's Role in Moderating the Effect of Financial Distress towards Going Concern Audit Opinion. International Journal of Financial Research, 11, 432.

Wubishet Jemaneh Deribe and Dereje Getachew Regasa . (2018). Factors Determining Internal Audit Quality: Empirical Evidence from Ethiopian Commercial Banks. Research Journal of Finance and Accounting Vol.4, No.6.

Xie., F. (2016). Competition, Auditor Independence And Audit Quality. A Dissertation Submitted To The Graduate Division Of The University Of Hawai'I At Mānoa In Partial Fulfillment Of The Requirements For The Degree Of Doctor Of Philosophy In Business Adminstr. University Of Hawai' I At Mānoa.

Yamane, T. (1967.)., Statistics: An Introductory Analysis. 2nd edition.

Zergaw Chemeda . (2016 ). The Assessment of Quality External Audit Services: Evidence from Grades 'A' Private Audit Firms of Ethiopia. MSC. Thesis. 